\title{
Aktivitas Antioksidan Ekstrak Metanol Daun Alpukat Menggunakan Metode DPPH
}

\author{
Zaiyar $^{1}$, Alfin Surya ${ }^{2}$, Anggun Syazulfa ${ }^{3}$ \\ ${ }^{1)}$ Program Studi Teknik Sipil Sekolah Tinggi Teknologi Pekanbaru \\ 2) Program Studi D-3 Analis Kesehatan Universitas Abdurrab Pekanbaru \\ ${ }^{3)}$ Jalan.Soekarno hatta No.11 A Pekanbaru
}

Respondence Email : alfin.surya@univrab.ac.id

\begin{abstract}
Free radicals are molecules that lose electrons in their outer orbitals so that the number of electrons becomes odd and unstable. Free radicals can damage various macromolecule cells including proteins, carbohydrates, fats. Antioxidants are compounds that can donate one or more electrons to free radicals. Avocado leaves contain high bioactive components that can be used as a source of natural antioxidants. Avocado leaves that have been dried, mashed and then shifted with methanol. The extracts were tested by phytochemical screening, including flavonpoid, phenolic, tannin and antioxidant activity using the DPPH (2,2-diphenyl-1-picrylhidrazyl) method. This method is based on the reduction of 2,2-diphenyl-1-picrylhydrazyl (DPPH) against free radicals which causes a change from purple to yellow 2,2-diphenyl-1-picrylhydrazyl) (DPPH). From the research, the IC50 values in avocado leaves were $118.8056 \mu \mathrm{g} / \mathrm{mL}$ and $7,276 \mu \mathrm{g} / \mathrm{mL}$ on ascorbic acid as a positive control. From the IC50 value obtained, it is known that the methanol extract of avocado leaves has strong antioxidant activity to fight free radicals.
\end{abstract}

Key words : Antioxidant, Radical, extract avocado, DPPH

\begin{abstract}
Abstrak
Radikal bebas merupakan molekul yang kehilangan elektron pada orbital terluarnya sehingga jumlah elektronnya menjadi ganjil dan tidak stabil. Radikal bebas dapat merusak berbagai sel makromolekul termasuk protein, karbohidrat, lemak. Antioksidan adalah senyawa yang dapat menyumbangkan satu atau lebih elektron kepada radikal bebas Daun alpukat mengandung komponen bioaktif tinggi yang dapat dimanfaatkan sebagai sumber antioksidan alami. Daun alpukat yang telah dikeringkan, dihaluskan kemudian dimeserasi dengan metanol. Ekstrak diuji dengan penampisan fitokimia antara lain uji Flavonpoid, Fenolik, Tanin dan aktivitas antioksidan menggunakan metode DPPH (2,2-diphenyl-1-picrylhidrazyl). Metode ini didasarkan reduksi 2,2-diphenyl-1-picrylhydrazyl (DPPH) terhadap radikal bebas yang menyebabkan terjadinya perubahan dari warna ungu menjadi warna kuning 2,2-diphenyl-1-picrylhydrazyl) (DPPH). Dari penelitian didapatkan nilai $\mathrm{IC}_{50}$ pada daun alpukat $118.8056 \mu \mathrm{g} / \mathrm{mL}$ dan $7,276 \mu \mathrm{g} / \mathrm{mL}$ pada asam askorbat sebagai kontrol positif. Dari nilai $\mathrm{IC}_{50}$ yang didapat diketahui bahwa ekstrak metanol daun alpukat memiliki aktivitas antioksidan yang kuat untuk melawan radikal bebas.
\end{abstract}

Kata kunci : Antioksidan, Radikal bebas, Ekstrak daun alpukat, DPPH

Received: 23 October 2020, Accepted : Mai 2021 - Jurnal Photon Vol.11 No.2

DOI : https://doi.org/10.37859/jp.v11i2.2225

PHOTON is licensed under a Creative Commons Attribution-ShareAlike 4.0 International License 


\section{Introduction}

Tanaman alpukat berasal dari Amerika Tengah dan Selatan. Di Indonesia tanaman alpukat merupakan keragaman hayati yang selalu ada disekitar kita, baik itu yang tumbuh secara liar maupun yang sengaja dibudidayakan. Tanaman alpukat keberadaannya tidak asing lagi bagi masyarakat (Semangun, 2018). Daun alpukat merupakan salah satu sumber antioksidan. Daun alpukat dapat membantu dalam mencegah atau memperlambat kemajuan berbagai stress oksidatif, ekstrak daun alpukat juga dapat digunakan sebagai antibakteri, antihipertensi, dan antidiabetes (Widarta dan Amata, 2016).

Antioksidan adalah senyawa yang dapat menunda atau memperkecil laju reaksi oksidasi pada bahan-bahan yang mudah teroksidasi dan mampu menghambat atau mencegah oksidasi pada substrat yang disebabkan oleh radikal bebas (Anwar, 2014). Radikal bebas merupakan molekul yang sangat reaktif karena memiliki elektron yang tidak berpasangan dalam orbital luarnya sehingga dapat bereaksi dengan molekul sel tubuh dengan cara mengikat elektron molekul sel tersebut. Anti aging yang diakibatkan oleh radikal bebas di dalam tubuh yang merusak asam lemak tak jenuh pada membran sel (Winarsi, 2007). Salah satu metode pengukuran radikal bebas oleh senyawa antioksidan adalah dengan menggunakan metode 2,2-diphenyl-1-picrylhydrazyl (DPPH). Metode 2,2-diphenyl-1-picrylhydrazyl (DPPH) merupakan suatu metode pengukuran antioksidan yang sederhana, cepat dan tidak membutuhkan banyak reagen. Metode ini didasarkan reduksi 2,2-diphenyl-1-picrylhydrazyl (DPPH) terhadap senyawa penghambat radikal bebas yang menyebabkan terjadinya perubahan dari warna ungu menjadi warna kuning 2,2-diphenyl-1-picrylhydrazyl) (DPPH) awal yang dapat diukur menggunakan spektrofotometer pada panjang gelombang $517 \mathrm{~nm}$. Aktivitas tersebut dinyatakan sebagai konsentrasi inhibisi $\mathrm{lC}_{50}$ yang diperoleh (Masrifah dkk., 2017). Menurut penelitian Mufida dkk., (2018), ekstrak daun alpukat mengandung senyawa metabolit sekunder yaitu alkaloid, flavonoid, saponin, tanin, triterpenoid dan steroid. Konsentrasi ekstrak daun alpukat yang relatif paling efektif untuk menurunkan kadar kolestrol dalam darah mancit adalah pada konsentrasi $10 \%(\mathrm{~b} / \mathrm{v})$ dengan $\alpha=0,05$.

\section{The Methods}

Sampel dalam penelitian ini adalah daun alpukat didapatkan dari pohon disekitar lingkungan perumahan yang berada di jalan Riau. Bahan larutan kimia berupa Akuades, larutan Metanol, $\mathrm{HCl}$ pekat, $\mathrm{FeCl} 3$ 1\%, logam magnesium, 2,2-diphenyl 1-picrylhydrazyl (DPPH) dan metanol grade HPLC. Alat yang digunakan dalam penelitian ini adalah microplate reader berthold model LB-941.

\section{Pembuatan ekstrak biji buah alpukat}

Siapkan daun alpukat yang telah dicuci dan dipotong menjadi potongan yang tipis. Daun alpukat tersebut dikeringkan menggunakan suhu ruangan. Daun alpukat yang sudah kering dihaluskan dan ditimbang sebanyak

Received: 23 October 2020, Accepted : Mai 2021 - Jurnal Photon Vol.11 No.2

DOI : https://doi.org/10.37859/jp.v11i2.2225

PHОтON is licensed under a Creative Commons Attribution-ShareAlike 4.0 International License 
10 gram, kemudian dimasukkan ke dalam botol kaca gelap, lalu tambahkan pelarut metanol sampai sampel terendam dan tutup rapat, biarkan selama 72 jam. Setelah 72 jam larutan disaring menggunakan kertas saring, filtratnya dimasukkan ke dalam botol vial dan diuapkan dengan cara dikering anginkan pada suhu ruangan hingga kering dan didapatkan ekstrak kental daun alpukat dengan pelarut metanol.

\section{Uji aktivitas antioksidan}

Uji aktivitas antioksidan dilakukan menggunakan mikroplate reader two fold delution dengan metode DPPH (2,2-diphenyl-1-picrylhydrazl) pada panjang gelombang $520 \mathrm{~nm}$ pada ekstrak biji buah alpukat. Sampel sebanyak $2 \mathrm{mg}$ dalam $2 \mathrm{~mL}$ metanol dengan konsentrasi 1000 ppm. Mikroplate terdiri dari baris A-H masingmasing berjumlah 12 sumur. Baris A dimasukkan sampel sebanyak $100 \mu \mathrm{L}$. Sebanyak $50 \mu \mathrm{L}$ metanol dimasukkan pada masingmasing sumur pada baris B-H. Baris A dipipet sebanyak $50 \mu \mathrm{L}$ dan dimasukkan ke baris $B$, baris $B$ dipipet $50 \mu \mathrm{L}$ dan dimasukkan ke baris $C$, dan dilakukan hal yang sama sampai baris $F$, baris $F$ dipipet $50 \mu \mathrm{L}$ lalu dibuang, sehingga didapatkan konsentrasi 1000 ppm, 500 ppm, 250 ppm, 125 ppm, 62,5 ppm, 31,25 ppm. Baris A sampai G ditambahkan $80 \mu \mathrm{L}$ DPPH dengan konsentrasi 40 ppm. Kemudian diinkubasi selama 30 menit ditutup dengan aluminium foil. Aktivitas penangkapan radikal bebas diukur sebagai penurunan absorbansi 2,2-diphenyl-1picrylhydrazl (DPPH) sebagai pembanding yaitu vitamin C dengan konsentrasi 50 ppm. Nilai \% inhibisi dihitung dengan menggunakan rumus :

$\mathbf{y}=\mathbf{a x}+\mathbf{b}$

Keterangan :

$\mathrm{y}=$ absorbansi sampel

$\mathrm{x}=$ konsentrasi sampel

Analisa data menggunakan persentase (\%) inhibisi analisis probit dengan membuat kurva hubungan antara persen hambatan dengan konsentrasi sampel dan selanjutnya dihitung nilai IC50 . Nilai \% inhibisi dihitung dengan menggunakan rumus :

$\%$ hambatan $=\frac{\text { Absorbansi Kontrol-Absorbansi Sampel }}{\text { Absorbansi Kontrol }} \times 100 \%$

\section{Result And Discussion}

\section{Hasil Uji Aktivitas Antioksidan}

Analisis aktivitas antioksidan ekstrak metanol daun alpukat menggunakan metode DPPH dengan microplate reader berthold model LB-941 pada panjang gelombang $520 \mathrm{~nm}$ menghasilkan nilai $\mathrm{IC}_{50}$ seperti yang terlihat pada tabel 1 berikut dengan grafik inhibisi tergambar di grafik 1 dengan pembanding positif asam askorbat terlihat pada tabel 2 :

Received: 23 October 2020, Accepted : Mai 2021 - Jurnal Photon Vol.11 No.2

DOI : https://doi.org/10.37859/jp.v17i2.2225

PHOTON is licensed under a Creative Commons Attribution-ShareAlike 4.0 International License 
Tabel 1. Ekstrak daun alpukat menggunakan pelarut metanol sebagai sampel

\begin{tabular}{ccc}
\hline $\begin{array}{c}\text { Konsentrasi metanol } \\
(\mu \mathrm{g} / \mathrm{mL})\end{array}$ & Ln Konsentrasi $(\mathrm{X})$ & \% Hambatan $(\mathrm{Y})$ \\
\hline 1000 & 6,908 & 94,833 \\
500 & 6,215 & 82,904 \\
250 & 5,521 & 65,560 \\
125 & 4,828 & 58,549 \\
62,5 & 4,135 & 38,376 \\
31,25 & 3,442 & 17,833 \\
\hline
\end{tabular}

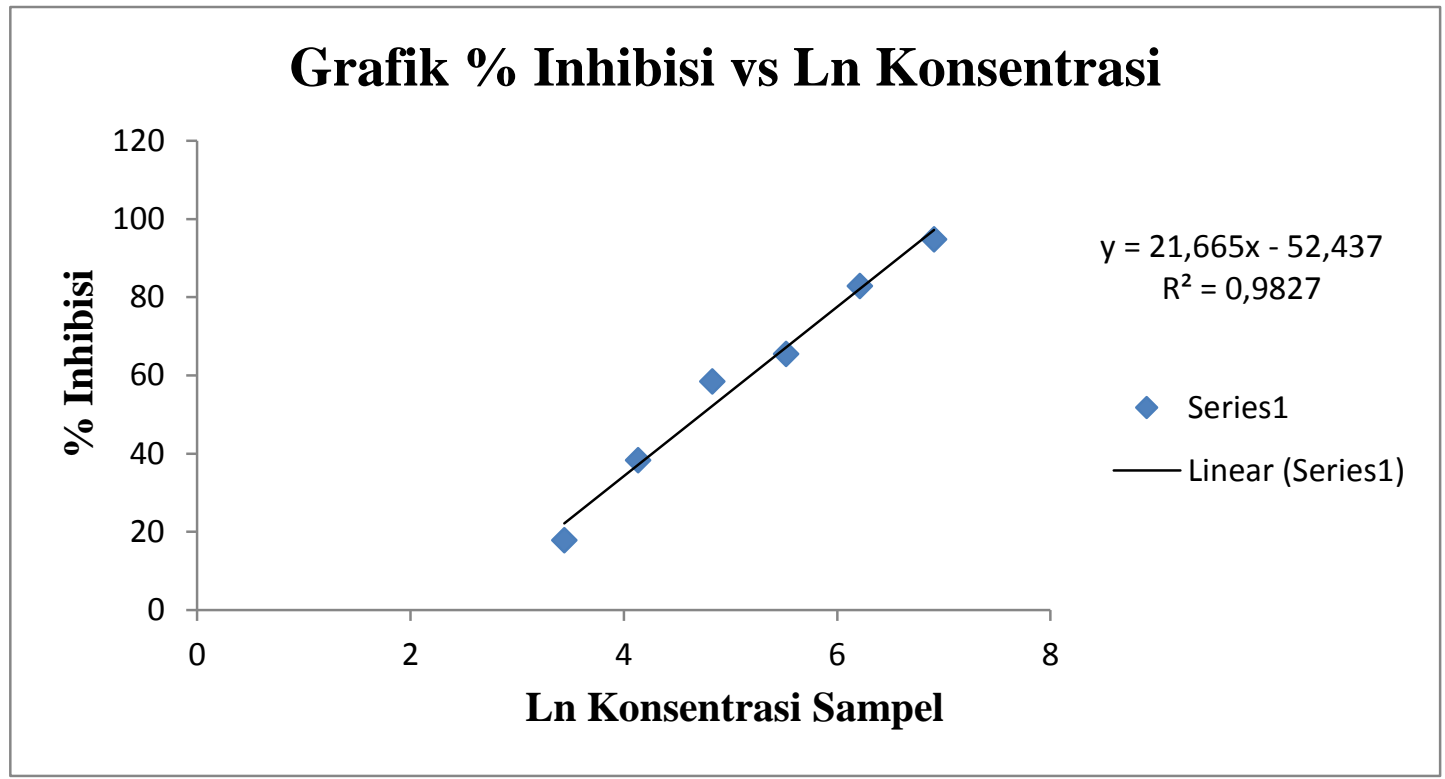

Grafik 1. Hubungan \% hambatan dengan konsentrasi sampel

Perhitungan $\mathrm{IC}_{50}$ dengan fraksi metanol.

Persamaan regresi linier :

$\mathrm{Y}=21,665 \mathrm{X}$

$50=21,665 \operatorname{Ln} X+(-52,437)$

Ln $\mathrm{X}=4,7282$

$\mathrm{X}=113,0947$

$\mathrm{IC}_{50}=113,0947 \mu \mathrm{g} / \mathrm{mL}$

Received: 23 October 2020, Accepted : Mai 2021 - Jurnal Photon Vol.11 No.2

DOI : https://doi.org/10.37859/jp.v17i2.2225

PHOTON is licensed under a Creative Commons Attribution-ShareAlike 4.0 International License 
Tabel 2. Asam Askorbat Sebagai Kontrol positif

\begin{tabular}{ccc}
\hline $\begin{array}{c}\text { Konsentrasi metanol } \\
(\mu \mathrm{g} / \mathrm{mL})\end{array}$ & Ln konsentrasi $(\mathrm{X})$ & \% Hambatan $(\mathrm{Y})$ \\
\hline 100 & 4,605 & 98,811 \\
50 & 3,912 & 84,016 \\
25 & 3,219 & 72,259 \\
12,5 & 2,526 & 60,502 \\
6,25 & 1,833 & 48,481 \\
3,125 & 1,138 & 33,554 \\
\hline
\end{tabular}

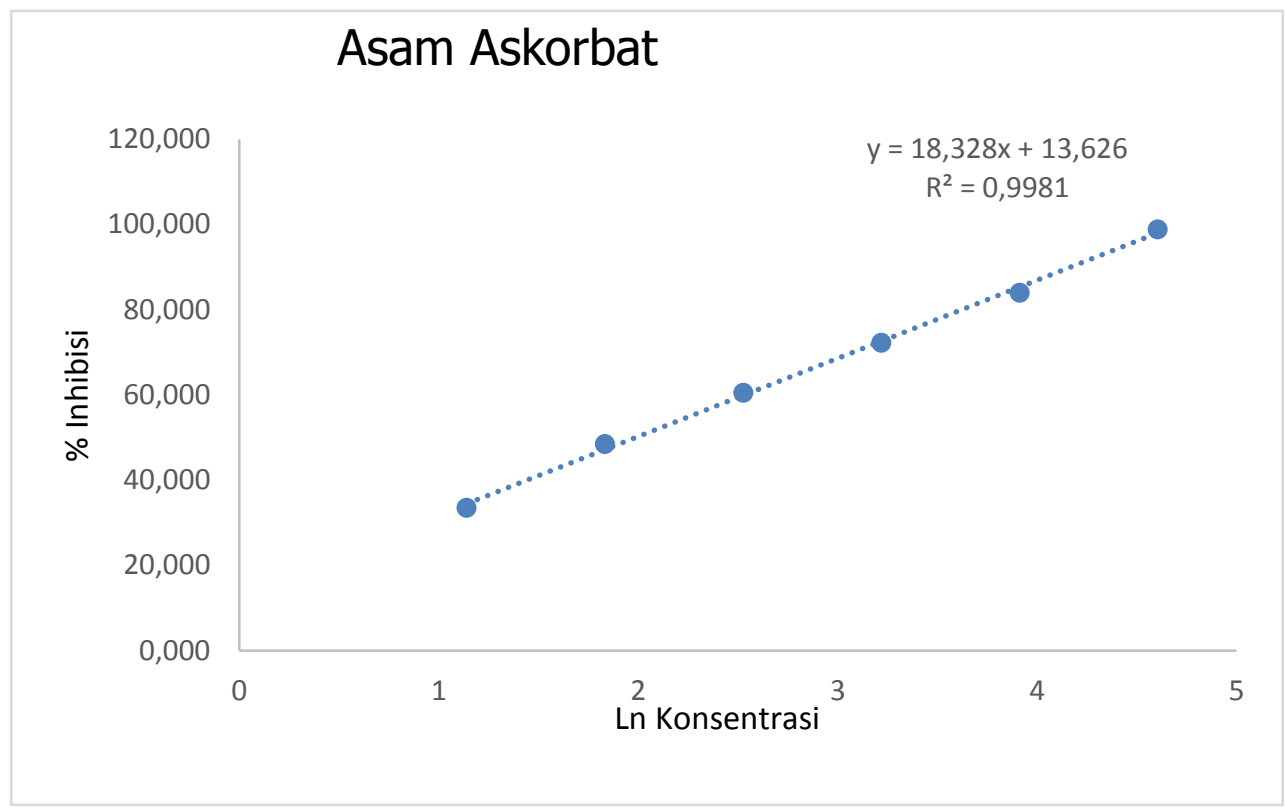

Grafik 2. Hubungan \% hambatan dengan konsentrasi asam askorbat

Perhitungan $\mathrm{IC}_{50}$ Asam Askorbat

Persamaan regresi liniear :

$\mathrm{Y}=18,328 \mathrm{X}+13,626$

$50=18,328 \mathrm{X}+13,626$

$\operatorname{LnX}=1,984$

$\mathrm{X} \quad=7,276$

$\mathrm{IC}_{50} \quad=7,276 \mu \mathrm{g} / \mathrm{mL}$

Received: 23 October 2020, Accepted : Mai 2021 - Jurnal Photon Vol.11 No.2

DOI : https://doi.org/10.37859/jp.v17i2.2225

PHОтON is licensed under a Creative Commons Attribution-ShareAlike 4.0 International License 


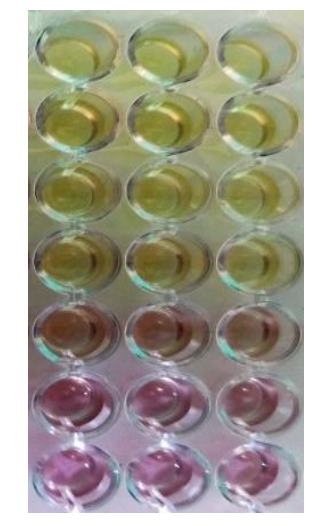

Gambar 3. Ekstrak Metanol Daun Alpukat

Pengujian antioksidan dengan menggunakan metode penangkal radikal bebas 2,2-diphenyl-1-picrylhydrazyl) (DPPH). Metode 2,2-diphenyl-1-picrylhydrazyl) (DPPH) merupakan metode yang sederhana, cepat dan mudah untuk penapisan aktivitas penangkapan radikal bebas, metode ini terbukti akurat dan praktis. Uji 2,2-diphenyl1-picrylhydrazyl) (DPPH) berperan sebagai radikal bebas yang mengandung senyawa nitrogen yang tidak stabil. Reagen DPPH yang bereaksi dengan antioksidan akan mengalami perubahan warna dari ungu ke kuning, intesitas warna tergantung kemampuan dari antioksidan (Masrifah dkk, 2017).

Aktivitas antioksidan dari suatu senyawa dapat digolongkan berdasarkan nilai $\mathrm{lC}_{50}$ yang diperoleh. Jika nilai $\mathrm{IC}_{50}$ suatu ekstrak berada dibawah 50 ppm maka aktivitas antioksidannya katagori sangat kuat, nilai $1_{50}$ berada diantara 50-100 ppm berati aktivitas antioksidannya kategori sangat kuat, nilai $\mathrm{lC}_{50}$ berada diantara 100-150 ppm berati aktivitas antioksidannya kategori sedang, nilai $1_{50}$ berada diantara 150-200 ppm berarti aktivitas antioksidannya katagori lemah, sedangkan apabila nilai $\mathrm{lC}_{50}$ berada diatas 200 ppm maka aktivitas antioksidannya dikategorikan sangat lemah (Bahriul, 2014). Pada kontrol positif asam askorbat didapatkan nilai IC50 sebesar 7,276 ( $\mu \mathrm{g} / \mathrm{mL})$ ini menunjukkan aktivitas antioksidan yang sangat kuat karena senyawa murni. Pada uji sampel ekstrak daun alpukat didapat 118,8056 $(\mu \mathrm{g} / \mathrm{mL})$ menunjukkan sampel ekstrak daun alpukat memiliki aktivitas antioksidan yang baik.

\section{Conclusion}

Hasil analisis pengujian aktivitas antioksidan pada ekstrak metanol kulit petai menggunakan metode DPPH didapatkan nilai $\mathrm{IC}_{50}$ sebesar $118,8056(\mu \mathrm{g} / \mathrm{mL})$. Hal ini menunjukkan bahwa esktrak metanol kulit petai memiliki aktivitas antioksidan yang kuat.

Received: 23 October 2020, Accepted : Mai 2021 - Jurnal Photon Vol.11 No.2

DOI : https://doi.org/10.37859/jp.v11i2.2225

PHOTON is licensed under a Creative Commons Attribution-ShareAlike 4.0 International License 


\section{Acknowledgement}

Peneliti mengucapkan terimakasih kepada Sekolah Tinggi Teknologi Pekanbaru dan teman-teman yang sudah memberikan bantuannya dalam menyelesaikan artikel ini.

\section{References}

Anwar, E. 2012. Eksipen dalam Sediaan Farmasi Karakterisasi dan Aplikasi. Dian Rakyat. Jakarta.

Masrifah. Rahma, N. dan Abram, H, P. 2017. Uji Aktivitas Ekstrak Daun dan Kulit Labu Air (Lagennaria siceruruai (Molina) Standl). Jurnal Akad.Kim. Volume 6 (2) : Halaman 96-106.

Mufida., Rahman, N, dan Supriadi. 2018. Efek Ekstrak Daun Alpukat (Persea Americana Miller) dalam Menurunkan Kadar Kolestrol Darah Pada Mancit (Mus musculus). Jurnal Akademik Kimia, Volume 7, No. 1, 2018: Halaman 11-18.

Semangun, H. 2007. Penyakit-Penyakit Tanaman Hortikultura Di Indonesia. Gadjah Mada University Press. Yogyakarta.

Widarta, R, W., dan Amata W. 2016. Ekstraksi Komponen Bioaktif Daun Alpukat dengan Bantuan Ultrasonik pada Berbagai Jenis dan Konsentrasi Pelarut. Agritech, Volume 37, No. 2, Mei 2017: Halaman 148-157.

Winarsi, H. 2007. Antioksidan Alami dan Radikal Bebas Potensi dan Aplikasinya dalam Kesehatan. Kanisus. Yogyakarta. 